\title{
Aplikasi Penentuan Tingkat Kesehatan Terumbu Karang Menggunakan Metode K-Nearest Neighbor dan Curve Fitting Berbasis Pengolahan Citra Digital
}

\author{
Christian Elric Y. Koba ${ }^{1}$, Chriestie E. J. C. Montolalu ${ }^{2}$, Altien J. Rindengan ${ }^{3 *}$ \\ 1,2,3 Program Studi Matematika, Fakultas Matematika dan Ilmu Pengetahuan Alam, \\ Universitas Sam Ratulangi Manado \\ *corresponding author email : altien@unsrat.ac.id
}

\begin{abstract}
Abstrak
Terumbu karang merupakan sebuah ekosistem laut yang secara langsung sangat mempengaruhi kehidupan manusia. Akan tetapi, terumbu karang telah banyak mengalami kerusakan yang ditandai dengan pemutihan terumbu karang. Tujuan dari penelitian ini yakni untuk membangun sebuah sistem aplikasi yang mampu melakukan klasifikasi kelas warna terumbu karang berdasarkan Coral Health Chart dengan menggunakan ciri warna RGB (red, green, blue) serta menentukan persentasi tingkat kesehatan terumbu karang tersebut. $K$ Nearest Neighbor merupakan metode yang digunakan untuk melakukan klasifikasi kelas warna terumbu karang. Dalam melakukan perhitungan persentase kesehatan terumbu karang digunakan metode Curve Fitting yang didasarkan pada rata-rata nilai RGB gambar terumbu karang. Penelitian ini menggunakan basis data citra Coral Health Chart. Sebagai data uji diambil 10 sampel citra terumbu karang. Baik K-Nearest Neighbor maupun Curve Fitting keduanya dapat digunakan untuk mengolah sebuah data berbentuk citra digital serta dapat diimplementasikan kedalam sebuah sistem aplikasi.
\end{abstract}

Kata Kunci: Terumbu Karang, K-Nearest Neighbor, Curve Fitting, Coral Health Chart, Image Processing.

\section{Application System Coral Health Level Determination Using K-Nearest Neighbor And Curve Fitting Method Based On Image Processing}

\begin{abstract}
Coral reefs are marine ecosystem that directly affect people's lives. However, coral reefs have been damaged by many factors which characterized by coral bleaching. The purpose of this research is to build an application system that is capable to classify the color class of coral reef based on Coral Health Chart using the characteristic of RGB (red, green, blue) color and to determine the percentage of the coral reef health. $K$ Nearest Neighbor is a method that is used to classify the color class of coral reefs. To calculate the health percentage of coral reefs, Curve Fitting is used based on the average value of RGB images of coral reefs. This research use imagery database of Coral Health Chart. As the test data, 10 samples image of the coral reefs were taken. Both K-Nearest Neighbor and Curve Fitting can be used to process a digital image data and can be implemented into an application system.
\end{abstract}

Keywords : Coral Reef, K-Nearest Neighbor, Curve Fitting, Coral Health Chart, Image Processing.

\section{Pendahuluan}

Terumbu karang adalah salah satu ekosistem tertua yang secara ekonomi dan biologi sangat penting di dunia. Meskipun demikian, terumbu karang menghadapi sejumlah ancaman serius, termasuk polusi dari daratan, dampak pemancingan, perubahan iklim, peningkatan keasaman laut, serta kurangnya kesadaran masyarakat. Ancaman-ancaman tersebut menyebabkan terumbu karang akhir-akhir ini mengalami kerusakan yang sangat parah yang ditandai dengan terjadinya pemutihan warna pada terumbu karang [1].

Dalam upaya pemantauan serta penanggulangan kerusakan terumbu karang, pada tahun 2006 dilakukan penelitian tentang Monitoring Coral Bleaching Using a Colour Reference Card dimana dalam penelitian tersebut berhasil membuat sebuah tabel kesehatan karang (Coral Health Chart) 
yang terdiri dari empat kelas warna yang dapat digunakan untuk memantau kesehatan karang berdasarkan warna karang. Penggunaan Coral Health Chart yakni membandingan warna karang yang diamati dengan warna-warna yang telah terdapat pada Coral Health Chart kemudian dicatat kode warna yang paling mendekati [2].

Penelitian yang berkaitan dengan terumbu karang lainnya yakni dibuat sebuah persamaan perubahan warna pada terumbu karang yang rusak dengan pendekatan pengolahan citra dan metode kuadrat terkecil yang didasarkan rata-rata nilai RGB, namun dalam penentuan klasifikasi kelas warna masih dilakukan secara manual yakni dengan mengandalkan penglihatan mata [3]. Pada tahun 2016 dilakukan penelitian tentang bagaimana menentukan tingkat kesegaran ikan selar berbasis pengolahan citra digital. Objek yang diamati adalah pada bagian mata yang nantinya akan menjadi dasar penentukan tingkat kesegaran ikan selar tersebut. Dengan mengambil rata-rata nilai RGB pada objek mata tersebut, diperoleh informasi berupa nilai numerik yang kemudian digunakan untuk membuat persamaan untuk mengetahui persentase tingkat kesegaran ikan selar. Proses pengujian dari 150 sampel mata ikan diperoleh 122 citra yang sesuai dan 28 citra yang tidak sesuai sehingga diperoleh akurasi sebesar $81.333 \%$ [4]. Dalam penelitian ini dengan basis pengolahan citra digital akan dilakukan klasifikasi kelas warna terumbu karang dengan mengekstrak ciri citra berdasarkan masing-masing nilai RGB. Metode klasifikasi yang akan digunakan yakni metode $K$-Nearest Neighbor. Selain melakukan pengklasifikasian, dalam penelitian ini juga akan dilakukan penentuan tingkat kesehatan terumbu karang dengan menggunakan metode Curve Fitting dalam hal ini menggunakan metode Regresi Polinomial. Basis data yang akan digunakan dalam yakni citra hasil ekstrasi dari Coral Health Chart. Penelitian ini menggunakan bantuan komputer untuk membangun sistem aplikasinya.

\section{Terumbu Karang Dan Coral Health Chart}

Terumbu karang adalah struktur di dasar laut berupa deposit kalsium karbonat di laut yang dihasilkan terutama oleh hewan karang. Karang adalah hewan tak bertulang belakang yang termasuk dalam Filum Coelenterata (hewan berongga) atau Cnidaria. Yang disebut sebagai karang (coral) mencakup karang dari Ordo Scleractinia dan Sub kelas Octocorallia (kelas Anthozoa) maupun kelas Hydrozoa [5]. Pemutihan karang ialah pemudaran warna karang akibat punahnya alga simbiotik yang hidup di dalam jaringan karang. Pada karang yang sehat, alga memberikan energi dan memunculkan warnanya. Bila terjadi pemutihan, alga akan mengalami stres dan terlepas dari jaringan karang sehingga warna karang memudar [6].

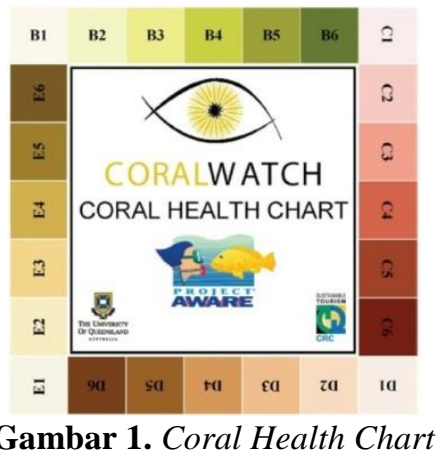

CoralWatch merupakan organisasi yang berpusat di University of Queensland, Brisbane, Australia. CoralWatch melakukan kegiatan pemantauan pemutihan karang secara global dan mengintegrasikannya dengan pendidikan konservasi terumbu karang. CoralWatch menggunakan Coral Health Chart atau Tabel Kesehatan Karang seperti pada gambar 1, suatu metode sederhana yang tidak merusak karang saat memantau pemutihan dan kesehatan karang. Dalam tabel tersebut terdapat empat klasifikasi warna, masing-masing mewakili warna-warna dari terumbu karang yaitu warna hijau, merah, coklat serta kecoklatan yang diberi kode pada masing-masing warna. 


\section{Pengolahan Citra Digital}

Secara umum, citra (image) adalah gambar pada bidang dua dimensi. Ditinjau dari sudut pandang matematis, citra merupakan fungsi kontinu dari intensitas cahaya pada bidang dua dimensi. Citra (image) merupakan salah satu komponen multimedia yang memegang peranan sangat penting sebagai bentuk informasi visual. Citra mempunyai karakteristik yang tidak dimiliki oleh data teks, yaitu citra kaya dengan informasi. Komponen warna utama yang membangun sebuah citra yakni Red, Green Blue (RGB) [7]. Sebuah citra digital adalah kumpulan piksel-piksel yang disusun dalam array dua dimensi. Indeks baris dan kolom $(x, y)$ dari sebuah piksel yang dinyatakan dalam bilangan bulat dan nilai-nilai tersebut mendefinisikan suatu ukuran intensitas cahaya pada titik tersebut. Satuan atau bagian terkecil dari suatu citra disebut piksel (picture element) [8].

Agar dapat diolah dengan komputer, maka suatu citra harus direpresentasikan secara numerik dengan nilai-nilai diskrit. Representasi citra dari fungsi kontinu menjadi nilai-nilai diskrit disebut digitalisasi. Citra yang dihasilkan inilah yang disebut citra digital (digital image). Citra digital yang berukuran $N \times M$ biasanya dinyatakan dengan matriks yang berukuran $N$ baris dan $M$ kolom sebagai berikut:

$$
f(x, y) \approx\left[\begin{array}{cccc}
f(0,0) & f(0,1) & \ldots & f(0, M-1) \\
f(1,0) & f(1,1) & \ldots & f(1, M-1) \\
: & : & : & : \\
f(N-1,0) & f(N-1,1) & \ldots & f(N-1, M-1)
\end{array}\right]
$$

Dimana $f$ merupakan komponen warna penyusun citra sementara $(x, y)$ merupakan letak pixel pada citra. Masing-masing elemen pada citra digital (berarti elemen matriks) disebut image element, picture element atau pixel. Setiap pixel memiliki warna tertentu, yang digambarkan dari nilai Red, Green dan Blue pada gambar tersebut seperti pada pada gambar 2. Setiap komponen memiliki nilai yang berada pada $0-255$, sehingga terdapat $255^{3}=16.777 .216$ kemungkinan warna yang berbeda pada suatu gambar. Dari jumlah bilangan bit yang dibutuhkan adalah 24, maka jenis gambar ini juga disebut gambar berwarna 24-bit [7].

Cropping image adalah suatu pengolahan citra dengan memotong satu bagian/area dari citra. Rumus yang digunakan :

$$
\begin{aligned}
& x^{\prime}=x-x L \text { untuk } \mathrm{x}=\mathrm{xL} \text { sampai } \mathrm{xR} \\
& \mathrm{y}^{\prime}=\mathrm{y}-\mathrm{yT} \text { untuk } \mathrm{y}=\mathrm{yT} \text { sampai } \mathrm{yB}
\end{aligned}
$$

Dimana $(x L, y T)$ dan $(x R, y B)$ adalah koordinat titik pojok kiri atas dan titik pojok kanan bawah citra yang akan dipotong [9].

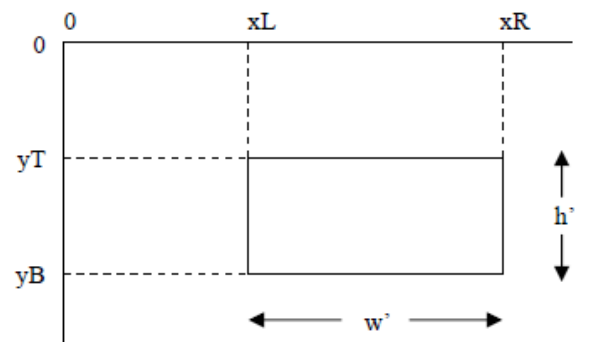

Gambar 2. Koordinat Perpotongan Citra

Ukuran citra akan menjadi :

Dimana :

$$
\begin{aligned}
& \mathrm{w}^{\prime}=\mathrm{xR}-\mathrm{xL} \\
& \mathrm{h}^{\prime}=\mathrm{yB}-\mathrm{yT}
\end{aligned}
$$

$$
\begin{aligned}
& \mathrm{w}^{\prime}=\text { lebar citra setelah dipotong } \\
& \mathrm{h}^{\prime}=\text { tinggi citra setelah dipotong }
\end{aligned}
$$

Contoh beberapa penelitian yang berkaitan dengan pengolahan citra digital yakni dilakukan penelitian tentang segmentasi citra digital mata ikan dengan menggunakan metode thresholding dimana dalam peneltian tersebut berhasil memisahkan objek mata ikan yang nantinya dapat berguna untuk mengenal jenis ikan [10]. Pernah juga dilakukan penelitian tentang perbaikan citra digital dengan menggunakan Filtering Technique dan Similitary Measurement yang mana dalam penelitian sebuah citra diberi noise kemudian diperbaiki kembali dan berhasil mendapatkan citra hasil 
perbaikan sangat mendekati citra aslinya [11]. Contoh lainnya, pada tahun 2016 dilakukan penelitian tentang klasifikasi batik menggunakan K-Nearest Neighbor berbasis Wavelet. Penelitian tersebut bertujuan untuk mempermudah pengenalan batik khususnya identifikasi/pengklasifikasian motif batik. Dasar pengklasifikasian menggunakan fitur-fitur warna dalam citra motif batik [12].

\section{K-Nearest Neighbor}

Algoritma Nearest Neighbor melakukan klasifikasi berdasarkan kemiripan suatu data dengan data yang lain. Metode K-Nearest Neighbor (K-NN) menjadi salah satu metode berbasis NN yang paling tua dan poluler. Nilai K yang digunakan di sini menggunakan jumlah tetangga terdekat yang dilibatkan dalam penentuan prediksi label kelas data uji. Dari K tetangga terdekat yang terpilih kemudian dilakukan voting kelas dari $\mathrm{K}$ tetangga terdekat tersebut. Kelas dengan jumlah suara tetangga terbanyaklah yang diberikan sebagai label kelas hasil prediksi pada data uji tersebut [13].

Algoritma K-NN adalah sebagai berikut :

1. Misalkan data uji $\mathrm{z}=\left(a^{\prime}, b^{\prime}\right)$, dimana :

- $\quad a^{\prime}$ adalah vektor/atribut data uji

- $\quad b^{\prime}$ adalah label kelas data uji yg belum diketahui

2. Hitung jarak data uji ke setiap data latih $\mathrm{D}\left(a^{\prime}, a\right)$, kemudian ambil K-tetangga terdekat pertama

3. Hitung jumlah data yang mengikuti kelas yangg ada dari K-tetangga tersebut. Kelas dengan data terbanyak menjadi label kelas dari data uji
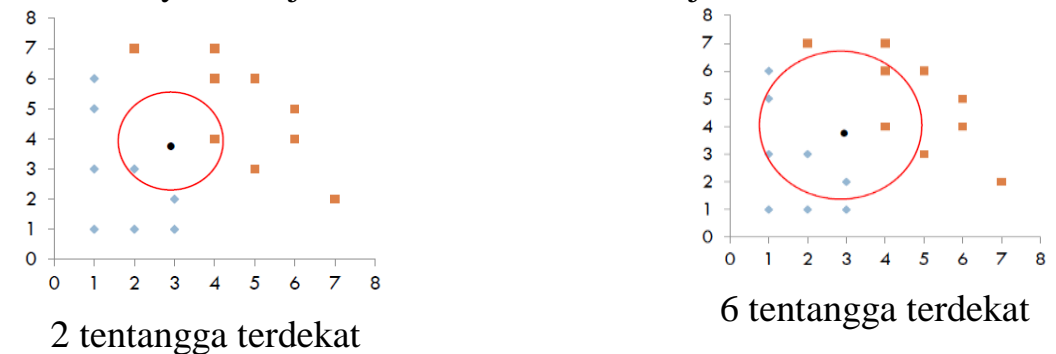

Gambar 3. Contoh Pemilihan Nilai K

\section{Curve Fitting (Pencocokan Kurva)}

Dalam banyak hal, kita sering bekerja dengan sejumlah data diskrit (umumnya berbentuk tabel). Data tersebut mungkin diperoleh dari hasil pengamatan di lapangan, pengukuran di laboratorium, atau tabel yang diambil dari buku acuan. Masalah yang sering muncul adalah menentukan harga diantara data-data yang sudah ada, tanpa harus melakukan pengukuran ulang. Misalkan tersedia datadata $y$ pada berbagai $x$ (sejumlah $n$ pasang), maka dapat dicari suatu persamaan $y=f(x)$ yang memberikan hubungan $y$ dengan $x$ yang mendekati data. Pendekatan seperti ini dalam metode numerik disebut Pencocokan Kurva (Curve Fitting). Ada dua metode pencocokan kurva yaitu interpolasi dan regresi [14].

Regresi polinomial digunakan menentukan fungsi polinomial yang paling sesuai dengan kumpulan titik data $\left(x_{r}, y_{r}\right)$ yang diketahui. Fungsi pendekatan :

$$
y_{i}=a_{0}+a_{1} x_{i}+a_{2} x_{i}^{2}+\cdots+a_{r} x_{i}^{r}+\varepsilon_{i}
$$

Dapat dihasilkan persamaan-persamaan berikut ini :

$$
\left.\begin{array}{c}
n a_{0}+a_{1} \Sigma x_{i}+a_{2} \Sigma x_{i}^{2}+\cdots+a_{r} \Sigma x_{i}^{r}=\Sigma y_{i} \\
a_{0} \Sigma x_{i}+a_{1} \Sigma x_{i}^{2}+a_{2} \Sigma x_{i}^{3} \ldots+a_{r} \Sigma x_{i}^{r+1}=\Sigma x_{i} y_{i} \\
a_{0} \Sigma x_{i}^{2}+a_{1} \Sigma x_{i}^{3}+a_{2} \Sigma x_{i}^{4} \ldots+a_{r} \Sigma x_{i}^{r+2}=\Sigma \mathrm{x}_{\mathrm{i}}^{2} y_{i} \\
\vdots \\
a_{0} \Sigma x_{i}^{r}+a_{1} \Sigma x_{i}^{r+1}+a_{2} \Sigma x_{i}^{r+2} \ldots+a_{r} \Sigma x_{i}^{r+r}=\Sigma \mathrm{x}_{\mathrm{i}}^{r} y_{i}
\end{array}\right\}
$$

Dalam menentukan nilai-nilai parameter yang belum diketahui yakni $a_{0}, a_{1}, a_{2}, \ldots, a_{r}$ dapat dicari dengan menggunakan persamaan di atas [14]. 
Algoritma regresi polinomial adalah sebagai berikut :

1. Tentukan $N$ titik data yang diketahui dalam $\left(x_{i}, y_{i}\right)$ untuk $i=1,2,3, \ldots, N$

2. Hitung nilai-nilai yang berhubungan dengan jumlahan data untuk mengisi matrik

3. Hitung nilai koefisien-koefisien $a_{0}, a_{1}, a_{2}, \ldots, a_{r}$ dengan menggunakan eliminasi Gauss/Jordan

4. Tampilkan fungsi polinomial $y=a_{0}+a_{1} x+a_{2} x^{2}+\cdots+a_{r} x^{r}$

5. Tampilkan hasil tabel $\left(x_{n}, y_{n}\right)$ dari hasil fungsi polinomial tersebut

Dalam melihat seberapa baik model persamaan yang diperoleh, dapat dihitung dengan menggunakan Sum Of Square Error (SSE) dengan rumus sebagai berikut:

$$
S S E=\sum_{i=1}^{n}\left(y_{\text {terhitung }}-y_{\text {data }}\right)^{2}
$$

Semakin kecil nilai SSE maka persamaan tersebut semakin baik, atau dapat dikatakan bahwa semakin kecil nilai SSE maka persamaan tersebut hampir melewati semua titik-titik data yang ada [15].

\section{Metodologi Penelitian}

\subsection{Waktu dan Tempat Penelitian}

Penelitian ini dilakukan pada bulan November 2016 sampai bulan Desember 2016 di Laboratorium Komputer Lanjut Jurusan Matematika F-MIPA Universitas Sam Ratulangi.

\subsection{Perancangan Sistem}

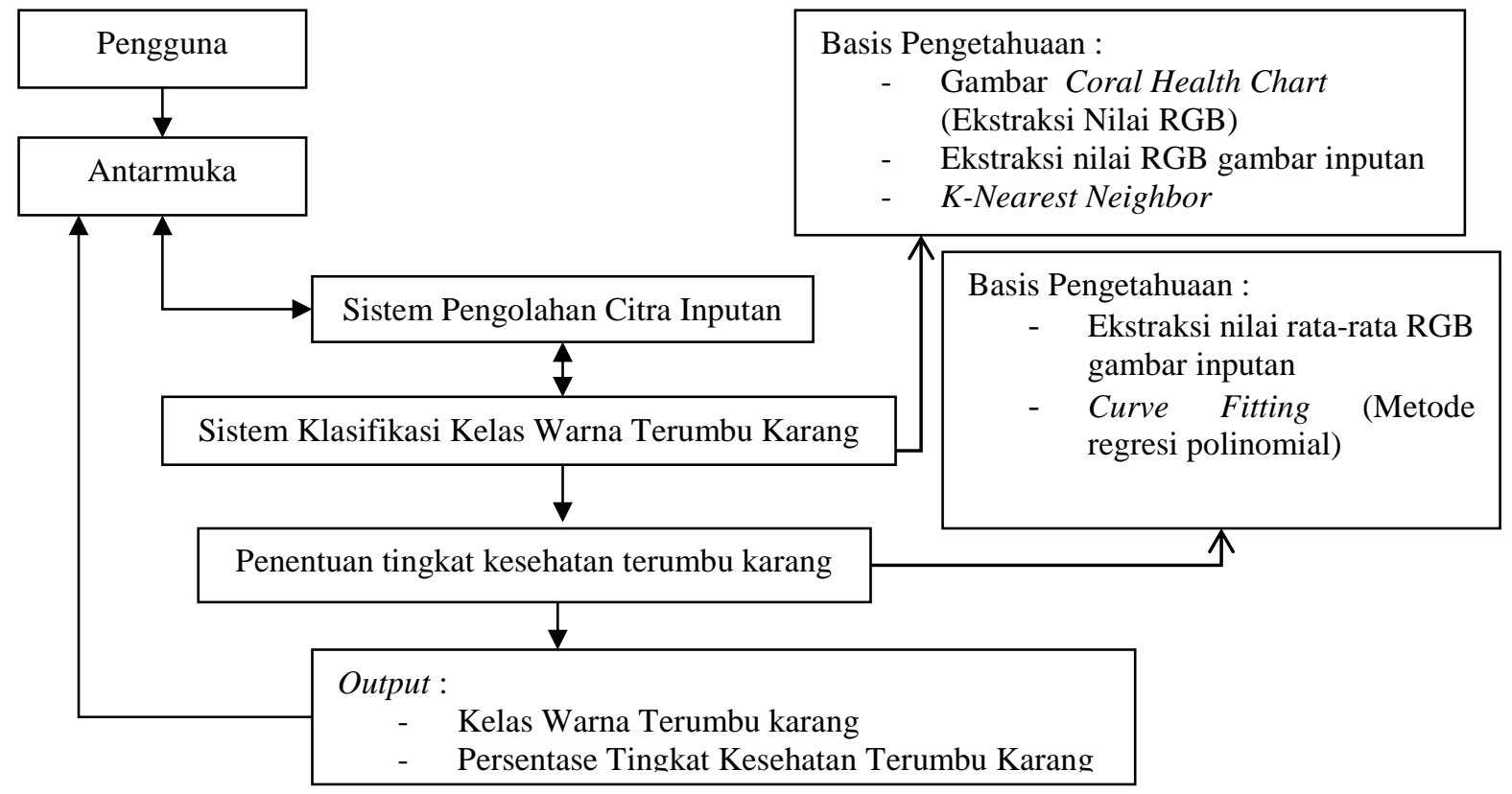

Gambar 4. Arsitektur Aplikasi Sistem Penentuan Kesehatan Terumbu Karang

Pada bagian sistem pengolahan citra inputan, akan dirancang sebuah sistem yang mampu mengolah citra inputan sebelum diproses. Bagian ini memungkinkan sistem dapat melakukan cropping citra inputan. Bagian sistem klasifikasi kelas warna terumbu karang adalah bagian untuk melakukan proses klasifikasi yang didasarkan pada ekstraksi nilai RGB citra inputan serta ekstraksi basis data citra Coral Health Chart yang kemudian dalam sistem dibuat algoritma berdasarkan metode $K$ Nearest Neighbor untuk proses klasifikasi. Pada tahap akhir, dibuat algoritma untuk melakukan perhitungan persentasi tingkat kesehatan terumbu karang yang didasarkan pada nilai rata-rata RGB citra inputan dan metode Curve Fitting. Sebagai kesimpulan terakhir, aplikasi sistem akan menampilkan kesimpulan berupa kelas warna terumbu karang dan persentase tingkat kesehatan terumbu karang. Algoritma pada sistem dibuat menggunakan bantuan software analisis matematika 


\section{Hasil dan Pembahasan}

\subsection{Ekstraksi Nilai RGB Citra Coral Health Chart Menggunakan Pengolahan Citra Digital}

Peneltian ini menggunakan basis data berupa sebuah citra yakni citra Coral Health Chart seperti pada gambar 5. Pengolahan citra digital digunakan untuk mengekstraksi nilai tiga warna primer dari citra yakni $R G B$ (Red, Green, Blue). Hasil Ekstraksi ini nantinya akan digunakan dalam program yakni sebagai basis pengetahuan yang akan dipakai pada program.

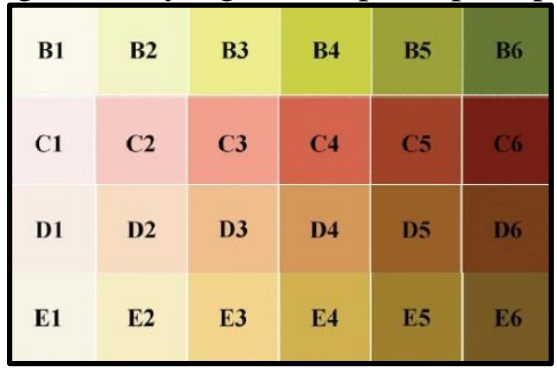

Gambar 5. Kelas Warna Coral Health Chart

Citra Coral Heatlh Chart terdiri dari empat kelas besar yakni $B, C, D$ dan $E$ dimana masingmasing terbagi atas enam interval kelas kecil. Misalnya untuk kelas $B$ terbagi atas $B 1, B 2, B 3, B 4$, $B 5$ dan $B 6$, begitu juga seterusnya untuk tiga kelas besar lainnya. Enam interval kelas kecil mengartikan perubahan warna dari terumbu karang atau bisa diartikan sebagai tingkat kesehatan dari terumbu karang. Bila dilihat dari gambar semakin besar nilai interval maka warnanya akan semakin gelap begitu juga sebaliknya. Ditinjau dari tingkat kesehatan terumbu karang, semakin gelap warnanya maka terumbu karang tersebut semakin sehat, sebaliknya bila warnanya semakin cerah/putih maka terumbu karang tersebut semakin tidak sehat.

Proses ekstraksi nilai $R G B$ menggunakan bantuan komputer yang menghasilkan rata-rata red, rata-rata warna green, rata-rata warna blue dan rata-rata $R G B$. Hasilnya seperti pada tabel 1.

Tabel 1. Rata-rata red, Rata-rata green, Rata-rata Blue dan Rata-rata $R G B$.

\begin{tabular}{|r|r|r|r|r|}
\hline Kelas & Rata-rata $R$ & \multicolumn{1}{|c|}{ Rata-rata $G$} & Rata-rata $B$ & \multicolumn{1}{c|}{ Rata-rata RGB $(x)$} \\
\hline B1 & 251.039 & 247.484 & 235.726 & 244.749 \\
\hline B2 & 243.509 & 245.259 & 198.192 & 228.987 \\
\hline B3 & 237.428 & 237.421 & 146.165 & 207.005 \\
\hline B4 & 203.223 & 209.849 & 75.857 & 162.976 \\
\hline B5 & 160.205 & 166.000 & 64.820 & 130.342 \\
\hline B6 & 107.885 & 126.798 & 59.870 & 98.184 \\
\hline C1 & 248.019 & 236.537 & 235.995 & 240.183 \\
\hline C2 & 246.086 & 201.893 & 195.701 & 214.560 \\
\hline C3 & 241.777 & 160.553 & 140.369 & 180.900 \\
\hline C4 & 211.973 & 100.778 & 76.953 & 129.901 \\
\hline C5 & 160.071 & 67.660 & 42.384 & 90.038 \\
\hline C6 & 117.752 & 32.454 & 22.129 & 57.445 \\
\hline D1 & 247.155 & 237.223 & 228.111 & 237.496 \\
\hline D2 & 247.004 & 220.765 & 194.227 & 220.666 \\
\hline D3 & 239.750 & 191.399 & 143.392 & 191.514 \\
\hline D4 & 213.511 & 153.533 & 92.020 & 153.021 \\
\hline D5 & 154.970 & 100.565 & 43.589 & 99.708 \\
\hline D6 & 120.392 & 65.471 & 28.893 & 71.585 \\
\hline E1 & 245.115 & 242.836 & 228.153 & 238.701 \\
\hline
\end{tabular}




\begin{tabular}{|c|r|r|r|r|}
\hline Kelas & \multicolumn{1}{|c|}{ Rata-rata $R$} & \multicolumn{1}{c|}{ Rata-rata $G$} & \multicolumn{1}{c|}{ Rata-rata $B$} & \multicolumn{1}{c|}{ Rata-rata RGB $(x)$} \\
\hline E2 & 246.259 & 237.618 & 196.175 & 226.684 \\
\hline E3 & 242.858 & 214.266 & 143.964 & 200.363 \\
\hline E4 & 209.949 & 178.827 & 83.126 & 157.301 \\
\hline E5 & 161.640 & 130.983 & 52.760 & 115.128 \\
\hline E6 & 123.437 & 94.931 & 42.495 & 86.955 \\
\hline
\end{tabular}

\subsection{Perumusan Persamaan Tingkat Kesehatan Terumbu Karang Menggunakan Curve Fitting}

Pada perumusan persamaan tingkat kesehatan terumbu karang menggunakan persamaan (2) berderajat tiga. Data yang akan digunakan adalah hasil ekstraksi nilai $R G B$ seperti pada tabel 1 . Ratarata warna $R G B$ sebagai variabel $x$ sementara untuk interval kelas kecil dari 1-6 akan menjadi variabel $y$. Citra Coral Health Chart terdiri dari empat kelas besar maka terdapat empat persamaan yang terbentuk. Plot serta persamaan keempat kelas warna tersebut disajikan pada Gambar 6 dan Gambar 7.
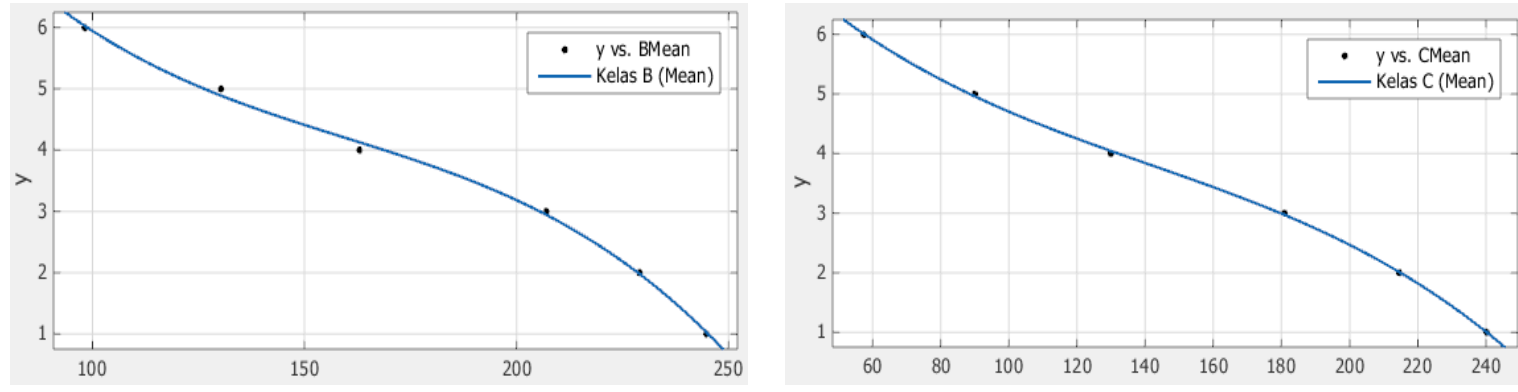

$y=16.37-0.1854 x+0.001026 x^{2}-0.000002143 x^{3}$

$y=9.114-0.07237 x+0.0003699 x^{2}-0.0000008713 x^{3}$

Gambar 6. Persamaan dan Plot Kelas Warna B dan C

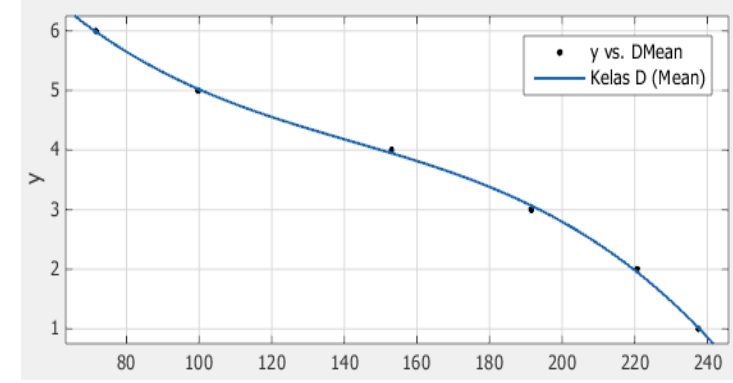

$y=11.47-0.1189 x+0.0007098 x^{2}-0.000001662 x^{3}$

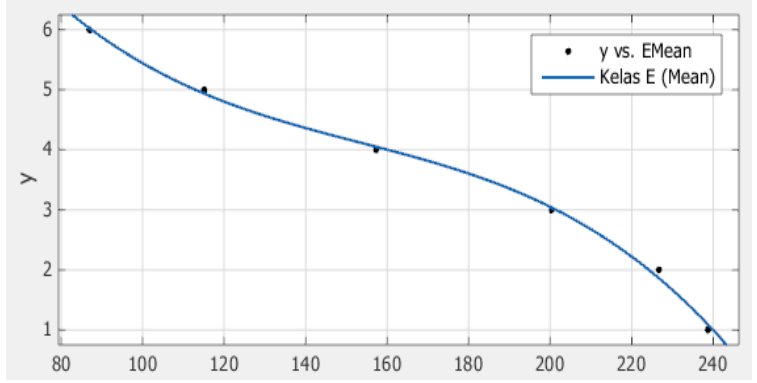

$y=15.179-0.1927 x+0.00114 x^{2}-0.000002473 x^{3}$

Gambar 7. Persamaan dan Plot Kelas Warna D dan E

Dengan menggunakan persamaan (4) maka keempat hasil persamaan yang didapat memilki nilai SSE sebagai berikut kelas $B=3.39 \%, C=0.04 \%, D=1,11 \%$ dan $E=3.62 \%$. Keempat persamaan diatas akan digunakan sebagai dasar penentuan persentase tingkat kesehatan terumbu karang dalam program. Cara penentuan persentase tingkat kesehatan terumbu karang yakni :

$$
\% \text { Kesehatan Terumbu Karang }=\frac{y}{6} \times 100
$$

Dimana nilai $y$ merupakan hasil dari hitungan persamaan yang melibatkan variabel $x$ (Rata-rata $R G B)$. 


\subsection{Implementasi dan Pengujian Sistem Aplikasi}

Implementasi serta pengujian sistem aplikasi merupakan tahapan untuk mengintegrasikan semua hal-hal yang dibutuhkan sistem kedalam sebuah perangkat lunak lewat rekayasa perangkat lunak.Pengujian sistem bertujuan untuk memeriksa apakah program berjalan sesuai perintah atau tidak.

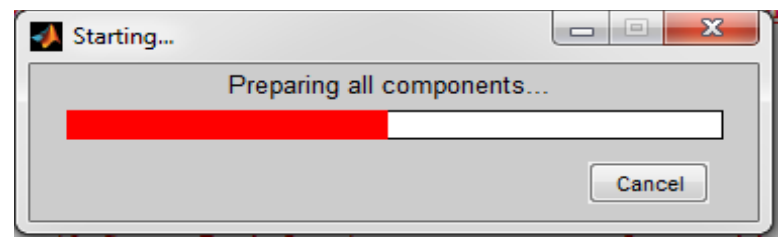

Gambar 8. Tampilan Pengecekan Sistem

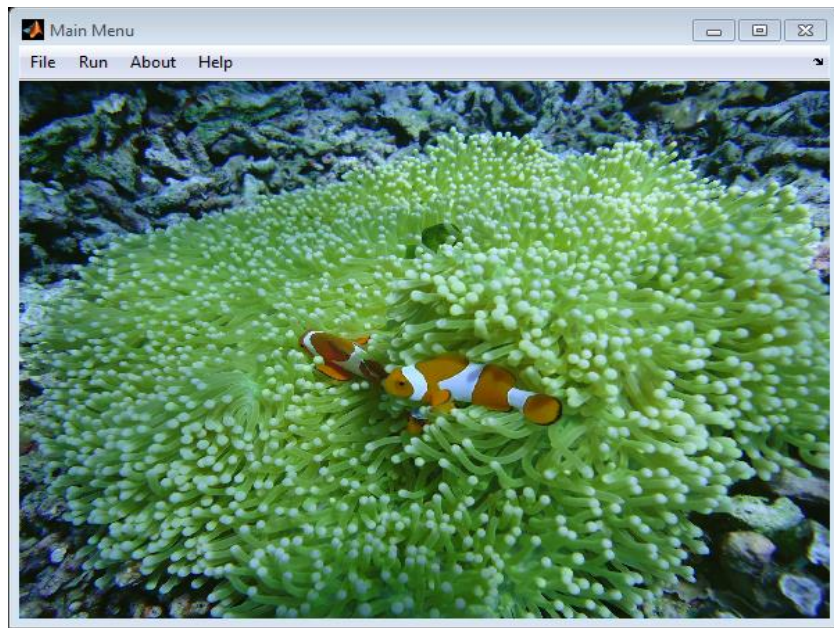

Gambar 9. Tampilan Jendela Main Menu

Pada jendela main menu terdapat menu bar yang terdiri dari File, Run, About, dan Help. Bagian program utama terdapat pada mеnu bar Run. Bila ditekan tombol program, maka akan muncul jendela seperti pada gambar 10 yang mana jendela tersebut diberi nama Analysis.

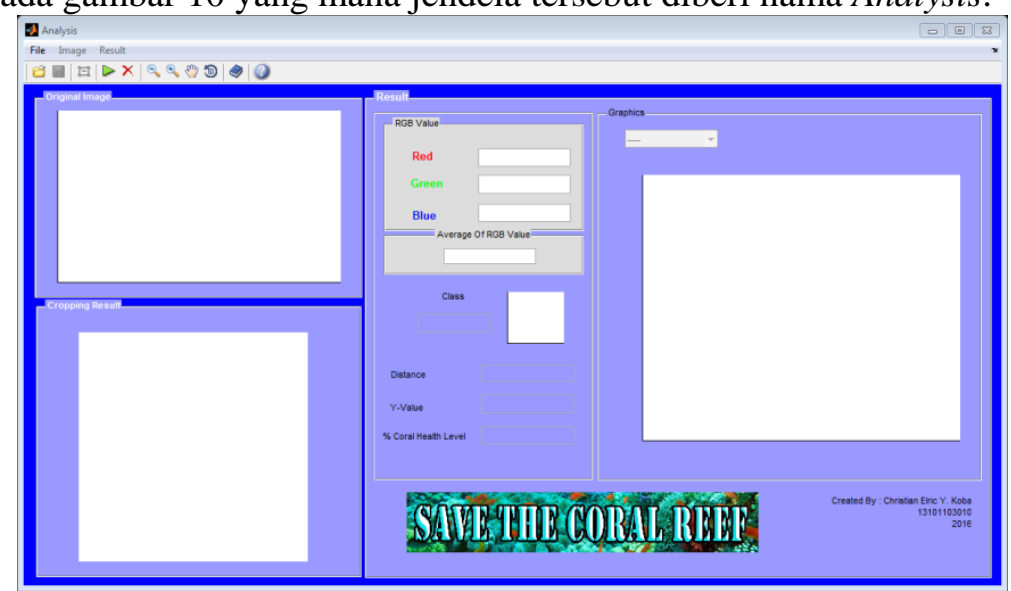

Gambar 10. Tampilan Jendela Analysis

Untuk pengujian sistem aplikasi maka langkah-langkah dalam program ini sebagai berikut :

1. Membuka citra yang akan dinalasisis dengan cara menekan tombol Open Image pada menu bar file atau dapat menggunakan tool bar

2. Pilih file citra yang akan digunakan dari harddrive komputer, kemudian tekan Open. Pada jendela analysis akan seperti gambar 12 . 


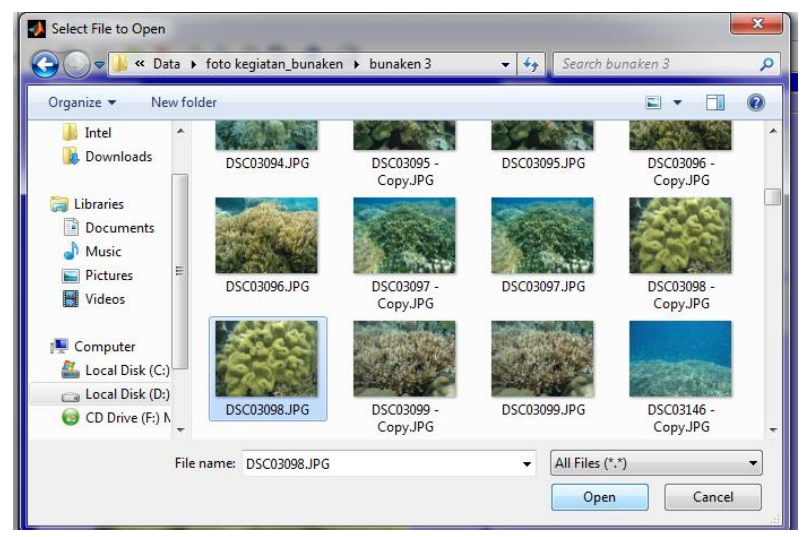

Gambar 11. Tampilan Jendela Pemilihan Citra Terumbu Karang

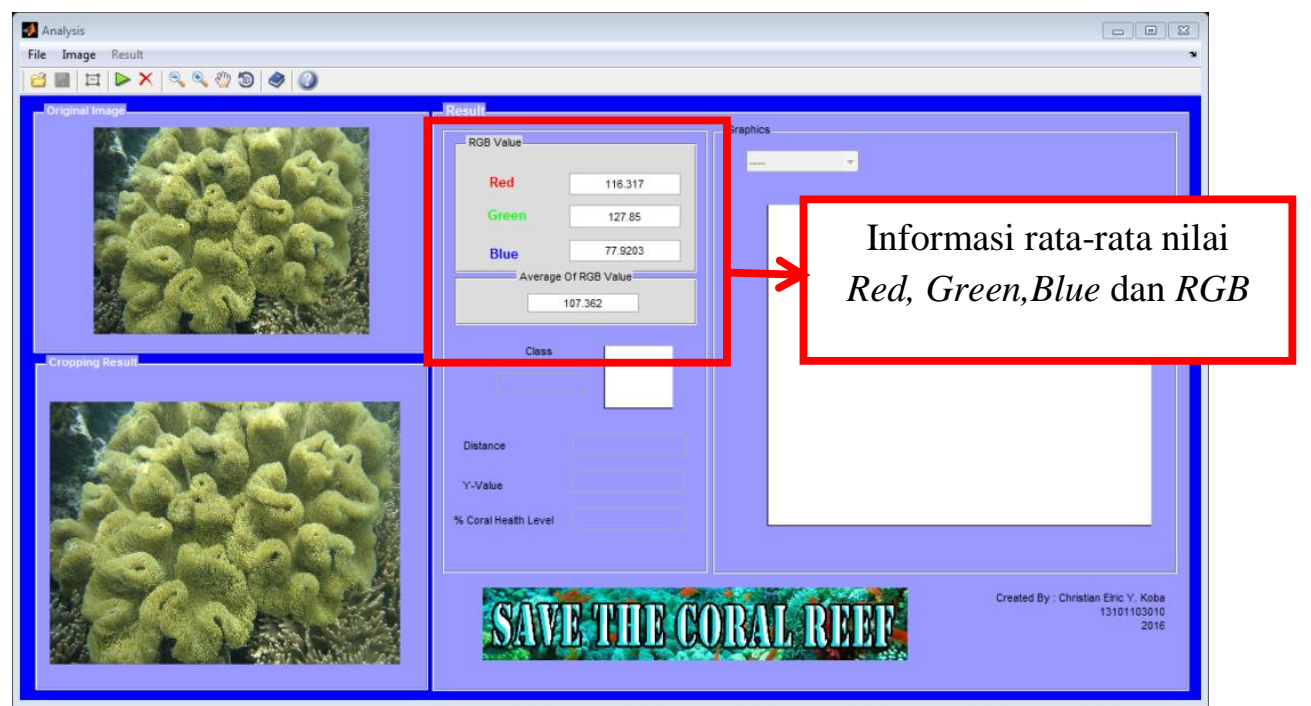

Gambar 12. Tampilan Jendela Analysis Menginput Citra Terumbu Karang

3. Karena citra terumbu karang yang dimasukan masih terdapat area yang tidak akan dianalisis maka akan dilakukan cropping dengan menggunakan tool crop image $\stackrel{[-1}{-}$ pada tool bar. Saat crop image ditekan maka akan muncul tampilan sebuah kotak yang menandakan batasan daerah yang akan dipotong seperti pada gambar 13. Kotak tersebut dapat diperbesar maupun diperkecil.

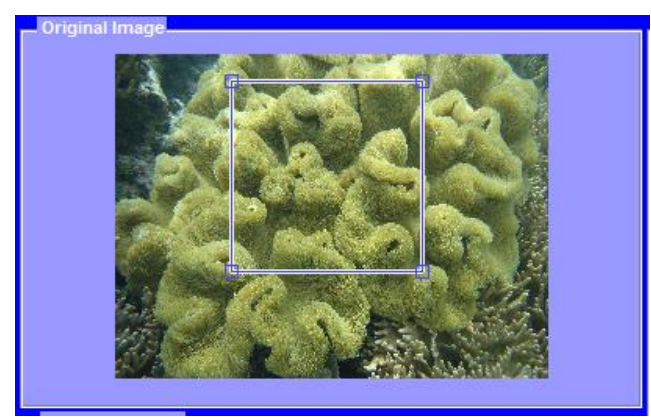

Gambar 13. Tampilan Cropping Image

Setelah dilakukan cropping maka tampilannya seperti pada gambar 14. 


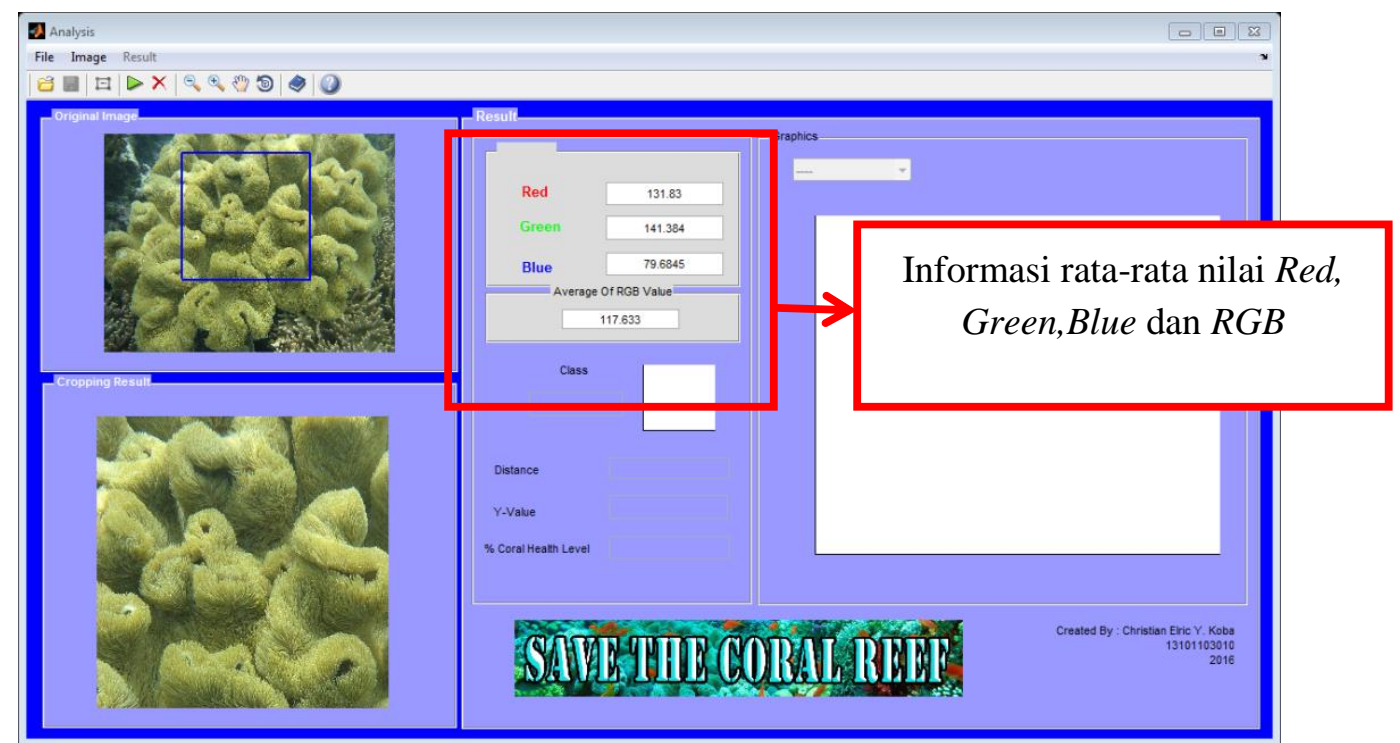

Gambar 14. Tampilan Setelah Cropping Image

4. Tekan tombol process $>$ pada tool bar untuk menganalisa citra inputan. Proses analisa akan menghasilkan klasifikasi kelas warna terumbu karang dan kesimpulan berupa persentase tingkat kesehatan terumbu karang seperti pada gambar 15. Selain itu dapat dilihat pula grafik analisisnya seperti pada gambar 16 .

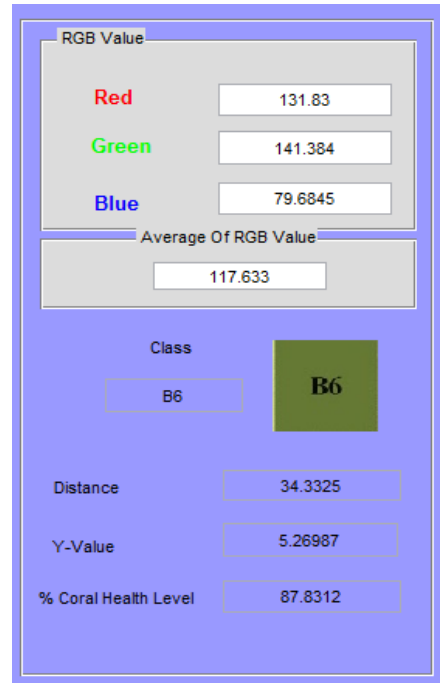

Gambar 15. Tampilan Kesimpulan Setelah Program Melakukan Analisa
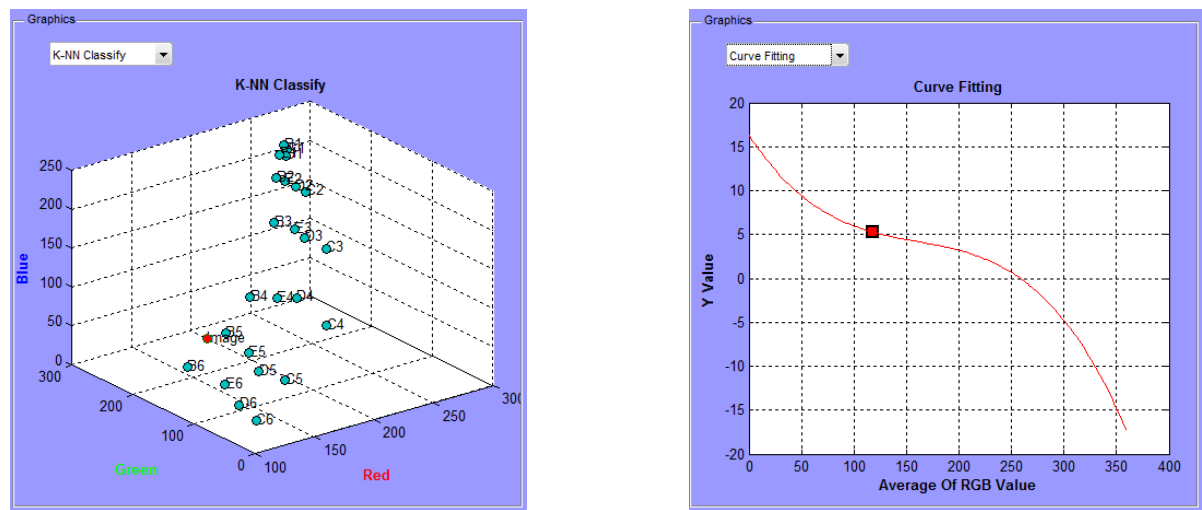

Gambar 16. Plot Grafik $K-N N$ Classify dan Curve Fitting 
5. Tekan tombol save to database untuk menyimpan hasil analisis. Bila data telah tersimpan makan tampilan jendela database seperti pada gambar 17.

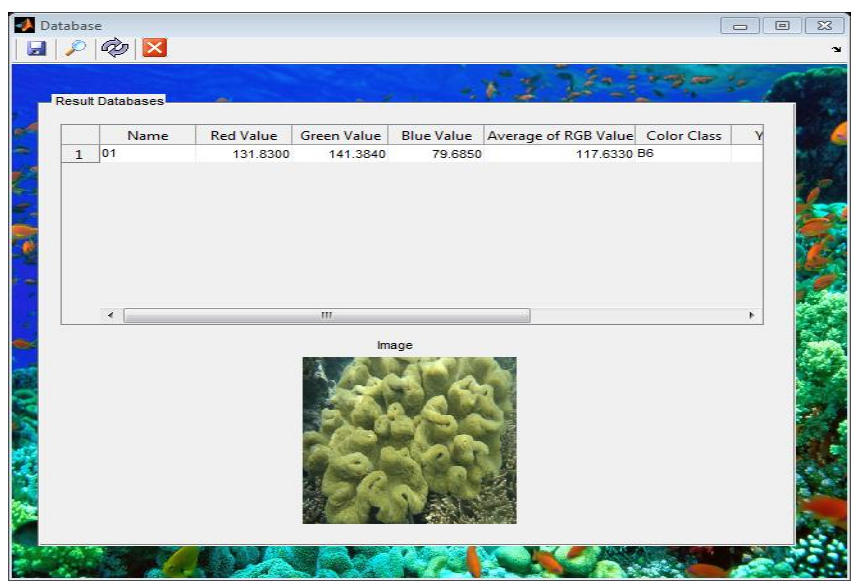

Gambar 17. Tampilan Jendela Database Setelah Hasil Analisis Disimpan

Setelah diuji, sistem aplikasi telah memberi hasil sesuai dengan apa yang telah diperintahkan. Adapun hasil pengujian 10 citra terumbu karang yang diambil dari perairan Taman Laut Nasional Bunaken dengan menggunakan kamera underwater $10 \mathrm{MP}$, seperti pada tabel 2.

Tabel 2. Hasil Analisis 10 Sampel Terumbu Karang

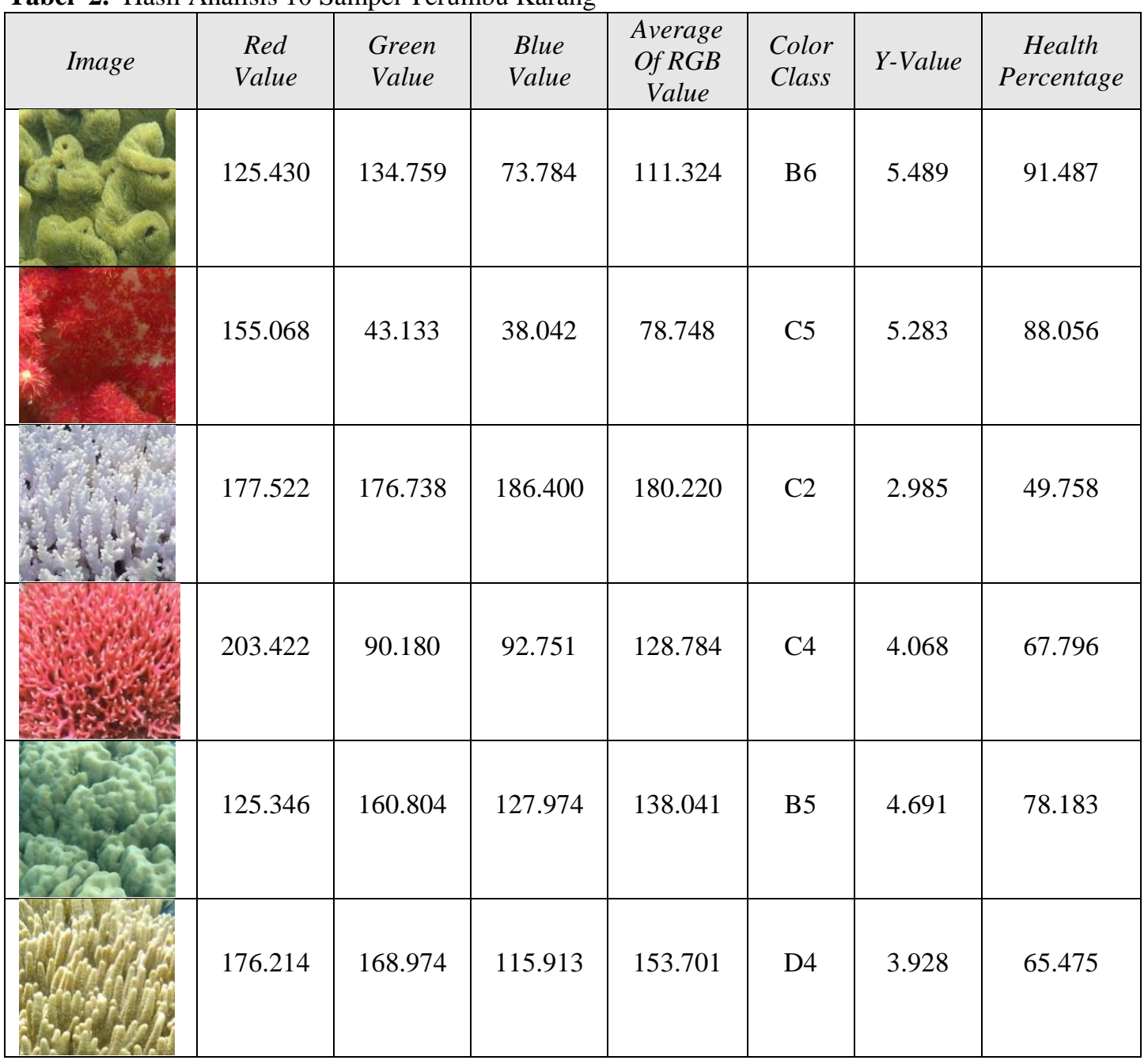




\begin{tabular}{|c|c|c|c|c|c|c|c|}
\hline Image & $\begin{array}{c}\text { Red } \\
\text { Value }\end{array}$ & $\begin{array}{c}\text { Green } \\
\text { Value }\end{array}$ & $\begin{array}{c}\text { Blue } \\
\text { Value }\end{array}$ & $\begin{array}{c}\text { Average } \\
\text { Of RGB } \\
\text { Value }\end{array}$ & $\begin{array}{c}\text { Color } \\
\text { Class }\end{array}$ & Y-Value & $\begin{array}{c}\text { Health } \\
\text { Percentage }\end{array}$ \\
\hline & 184.202 & 95.293 & 142.884 & 140.793 & $\mathrm{C} 4$ & 3.826 & 63.759 \\
\hline & 194.416 & 165.035 & 75.257 & 144.903 & $\mathrm{E} 4$ & 3.669 & 61.142 \\
\hline & 126.572 & 123.095 & 69.831 & 106.499 & $\mathrm{~B} 6$ & 5.673 & 94.558 \\
\hline & & & & & & \\
\hline
\end{tabular}

Bila dibandingkan dengan penelitian sebelumnya yang dilakukan pada tahun 2015 dimana menggunakan regresi sederhana [3], regresi polinomial memiliki tingkat ketelitian yang lebih tinggi atau dapat dikatakan memiliki nilai error yang lebih kecil. Hal tersebut dikarenakan regresi polinomial memungkinkan kita untuk membuat sebuah persamaan garis dengan derajat lebih dari satu yang artinya akan membetuk sebuah kurva yang tidak hanya garis lurus akan tetapi dapat dibentuk sebuah kurva yang mengikuti pola titik-titik data. Dilihat dari perbandingan error dalam hal ini menggunakan SSE, rata-rata nilai SSE untuk keempat persamaan pada penelitian sebelumnya yakni $32.646 \%$ [3], sementara pada penelitian ini yang mana menggunakan regresi polinomial memiliki rata-rata nilai SSE untuk keempat persamaan yakni $2.147 \%$.

\section{Kesimpulan}

1. Berdasarkan data citra Coral Health Chart serta citra terumbu karang, Metode K-Nearest Neighbor dapat digunakan untuk mengklasifikasikan citra digital berdasarkan komponen warna utama yakni red, green dan blue dengan cukup baik. Hasil tersebut terlihat pada klasifikasi kelas warna sampel terumbu karang yang secara kasat mata terlihat cocok dengan keluaran sistem aplikasi.

2. Metode Curve Fitting dapat diimplementasikan untuk menarik sebuah persamaan yang mewakili titik-titik data rata-rata nilai $R G B$ dari citra coral health chart yang kemudian digunakan sebagai dasar penentuan persentase tingkat kesehatan terumbu karang.

3. Berdasarkan hasil pengujian 10 sampel citra terumbu karang yang diambil pada perairan Taman Laut Nasional Bunaken, sistem aplikasi mampu memproses semua citra dengan rata-rata persentase tingkat kesehatan $75.18188 \%$.

\section{Daftar Pustaka}

[1] NOAA. 2009. Terumbu Karang. http://oceanexplorer. noaa. gov/ okeanos/ explorations/ 10index/ background/info/media /corals_fact_sheet_bahasa.pdf. [5 Oktober 2016].

[2] Siebeck, U.E., N.J. Marshall, A. Kluter, and O.H. Guldberg. 2006. Monitoring Coral Bleaching using Colour Reference Card. Coral Reefs 25:453-460. 
[3] Mandagi, A., L. Latumakulita., dan A. Rindengan. 2015. Identifikasi Tingkat Kesehatan Karang Berdasarkan Coral Health Chart Menggunakan Pengolahan Citra Digital Dan Metode Kuadrat Terkecil. Jurnal de Cartesian 4(1):42-50.

[http://ejournal.unsrat.ac.id/index.php/decartesian/article/view/7590]

[4] Bee, D., W. Weku., dan A. Rindengan. 2016. Aplikasi Penentuan Tingkat Kesegaran Ikan Selar Berbasis Citra Digital Dengan Metode Kuadrat Terkecil. Jurnal de Cartesian 5(2):121130 [http://ejournal.unsrat.ac.id/index.php/decartesian/article/view/14985]

[5] Suharsono. 2008. Jenis-jenis Karang Di Indonesia. LIPI. Jakarta

[6] CoralWatch. 2014. Pemutihan Karang. http://id.coralwatch.org/coral-bleaching. [2 Oktober 2016].

[7] Gonzales, R., dan R. Woods. 2008. Digital Image Processing third edition. Pearson. New Jersey.

[8] Mabrur, A. 2011. Pengolahan Citra Digital Menggunakan Matlab. Modul : ITS. Tulungangung.

[9] Kusumaningsih, I. 2009. Ekstraksi Ciri Warna, Bentuk, dan Tekstur Untuk Temu Kembali Citra Hewan [Skripsi]. FMIPA IPA, Bogor.

[10] Kumaseh, M., L. Latumakulika., dan N. Nainggolan. 2013. Segmentasi Citra Digital Ikan Menggunakan Metode Thresholding. Jurnal Ilmiah Sains 13(1):74 - 79.

[http://ejournal.unsrat.ac.id/index.php/JIS/article/view/2057]

[11] Saselah, G., W. Weku., dan L. Latumakulika. 2013. Perbaikan Citra Digital dengan Menggunakan Filtering Technique dan Similitary Measurement. Jurnal de Cartesian 2(2):

1-9. [http://ejournal.unsrat.ac.id/index.php/decartesian/article/view/3203]

[12] Dhian, I., dan K. Nugraha. 2016. Klasifikasi Batik Menggunakan KNN Berbasis Wavelet. Seminar Nasional Teknologi Informasi Dan Komunikasi (SENTIKA 2016) : 615-623. [https://fti.uajy.ac.id/sentika/publikasi/makalah/2016/27.pdf]

[13] Tan, P., M. Steinbach., V. Kumar. 2006. Introduction to Data Mining. Pearson Education. New York.

[14] Widodo, S. 2015. Metode Numerik. Graha Ilmu. Yogyakarta

[15] Iskandar, D. 2014. Metode Numerik. STIMIK-AMIK Riau. Pekanbaru 